IRSH 60 (201 5), Special Issue, pp. I 3-39 doi:I0. I0I7/So0208590 I 50004I 3

(C) 2015 Internationaal Instituut voor Sociale Geschiedenis

\title{
Migration and Ethnicity in Coalfield History: Global Perspectives
}

\author{
A D K N O T T E R
}

\section{Sociaal Historisch Centrum voor Limburg at Maastricht University Sint-Pieterstraat 7, 62 I I JM Maastricht, The Netherlands}

E-mail: a.knotter@maastrichtuniversity.nl

\begin{abstract}
AвSTRACT: This article provides a general background to the case studies in this Special Issue by highlighting some general themes in the history of migration to coalfields worldwide. All over the world, mining companies have struggled with labour shortages and had to find ways to recruit sufficient numbers of mineworkers. The solutions adopted ranged from the involvement of part-time peasant miners, organized mediation by labour contractors, and systems of forced labour, to state regulation of national and international migration. The importance of these kinds of "intervening institution" in mobilizing labour for the coalmines is illustrated by examples from different parts of the world. Efforts to find new workers for the mines often resulted in the recruitment of ethnic groups of a lower social status, not only because they were rural and unskilled, but also because they were considered inferior from a cultural or ethnic viewpoint. In this respect there was a huge difference from the migration and settlement of skilled miners, like those from Britain and other countries. Ethnic differences were often closely related to differences in skill and social status. Although there are many instances of inter-ethnic solidarity and cooperation, depending on the time-frame and circumstances, these differences could have a profound effect on social relations in mining communities.
\end{abstract}

In this article I give an overview of the most relevant issues in the history of migration and ethnicity in coalmining from a global perspective. I will refer to articles in this Special Issue where possible, but also to the very rich literature on coalfields elsewhere in the world. The article is roughly divided into four parts. The first part deals with the recruitment of migrants and ethnic minorities in upcoming coalfields in the nineteenth century and the first few decades of the twentieth century in areas where wage labour markets were underdeveloped. This was the case in colonies of the British Empire, such as India, South Africa, and Nigeria, but also in countries that at that time were less developed, such as Japan, China, and Ukraine. In these cases mining companies had to rely on temporary 
migrants, peasant miners from the land; on special recruitment systems, mainly subcontracting; or on systems of coercion, such as convict labour, indentured/contract labour, or blunt force and violence.

The second part of the article deals with diasporas of specific groups, such as skilled British workers, who migrated all over the world to introduce mining skills and often took a position of privilege vis-à-vis unskilled workers from other ethnic groups, including African Americans or eastern European migrants in the United States. British migrants were particularly important in the coalmines in the white settler colonies of South Africa, Canada, Australia, and New Zealand, and also in the emerging coal industry of the United States. Another mobile group were Polish miners, both in Europe and in the United States. At first, Polish miners were often skilled migrants from Silesia or the German Ruhr (one of their first migration destinations), but most subsequent Polish migrants were peasants or landless rural labourers, migrating to coalfields as unskilled workers.

The third part deals with state-regulated migration to the coalfields of western Europe (Britain excepted), which started after World War I and became fully developed after World War II. This was the so-called "guestworker" system, which brought migrants at first from eastern Europe and later from the Mediterranean periphery to Germany, France, Belgium, and the Netherlands. I pay special attention to Turkish migrants in Germany, Italian migrants in France and Belgium, and Moroccan migrants in France, Belgium, and the Netherlands, but at different phases migrants from several other countries were involved, both from eastern Europe (Czechoslovakia and Hungary, for instance) and from the Mediterranean (Yugoslavia, Spain, and Greece being examples).

The fourth part of this article looks at the social relationship of migrants and established workers in the mining communities. How did different ethnic groups live together? How did they cope with racial discrimination and ethnic segregation? To what extent could new groups of workers and their families integrate in the mining community?

\section{PEASANT MINERS AND OSCILLATING MIGRATION}

In emerging coalfields, large parts of the labour force were recruited seasonally as peasant migrants from the land. In this way labour supply and the agrarian seasons were interconnected, coal extraction proceeding in reverse tandem with agrarian seasons. Seasonal peasant workers were recruited both locally and as temporary migrants. A striking example of the local recruiting of peasant miners is the labour system in the Zonguldak coalfield in Turkey, as described by Erol Kahveci in this Special Issue, where an intricate system of rotational work was installed in the nineteenth 
century (since the 1860 ), forcing peasants from villages in the region to work underground during several weeks of the year. ${ }^{1}$ In 1965 rotational workers were still drawn from some 377 villages located throughout the province of Zonguldak. Force was no longer used, however, as working in the mines had become a family tradition, handed down from father to son. ${ }^{2}$

In the large Jahria coalfield in India (opened in the I890s), "recruited" or seasonal workers comprised 50 to 75 per cent of the workforce by the I 920 s, compared with "settled" migrants who made up is to 25 per cent and "local" workers amounting to only 5 to io per cent. Peasants and landless labourers, who were seasonally unemployed, and often indebted, came to work in the coalfields to keep the village households functioning. The mining workforce, male and female working together in family teams, was mainly "low caste" and "tribal" (so-called Adivasi, or "aboriginals"); "upper caste" were to be found only in the supervisory grades. ${ }^{3}$

Seasonal peasant workers, mainly from Russia, were also recruited on a massive scale for the Donbass coalmines in Ukraine. The first mineworkers in Juzovka (renamed Stalino at the end of the I920s, today's Donetsk) were winter migrants, who returned to their villages for the planting, fieldwork, and the harvest. In the mid-I 880 s, 60 to 70 per cent of Donbass workers were migratory, and in I904 $3 \mathrm{I} .7$ per cent of the coal cutters were away from the mines in the summer. ${ }^{4}$ The seasonal pendulum of village to mine was mixed with other types of wandering. For a long time, employers were unable to consolidate the workforce, and a more stable working class emerged only relatively late. The local population being persistently reluctant to enter the mines, Russian migrants and migratory workers formed the rank and file of the mining labour force. In i 889 only s per cent of miners were of local origin. ${ }^{5}$ The seasonal migration of peasant miners in the Donbass persisted well into the early Soviet period (I920s). Again, most

I. On the early history of the Zonguldak coalfield see also Donald Quataert, Miners and the State in the Ottoman Empire: The Zonguldak Coalfield, I 822-I920 (New York [etc.], 2006).

2. Delwin A. Roy, "Labour and Trade Unionism in Turkey: The Eregli Coalminers", Middle Eastern Studies, I 2:3 (1976), pp. I 25-172, I 26-I 34.

3. Dilip Simeon, The Politics of Labour under Late Colonialism: Workers, Unions and the State in Chota Nagpur 1928-1939 (New Delhi, 1995), p. 28; idem, "Coal and Colonialism: Production Relations in an Indian Coalfield, c. I 895-1947", International Review of Social History, 4I (1996), pp. 83-108, 93-94; C.P. Simmons, "Recruiting and Organizing an Industrial Labour Force in Colonial India: The Case of the Coal Mining Industry, c.I 880-1939", The Indian Economic and Social History Review, I 3 (1976), pp. 455-585, 458-460. On the seasonality of migrant labour in the Jahria coalfield, also leading to ethnic specialization, see Prabhu Prasad Mohapatra, "Coolies and Colliers: A Study of the Agrarian Context of Labour Migration from Chotanagpur, I 880-1920", Studies in History, I (1985), pp. 247-303, 283-297.

4. Theodore H. Friedgut, Iuzovka and Revolution, I: Life and Work in Russia's Donbass, I869-1924 (Princeton, NJ, 1989), pp. 209, 215 n. 80, 217 , and 221.

5. Ibid., pp. 2 I I-2 I 2. 
of them (about 75 per cent) were Russians. Seasonal migration greatly diminished after forced collectivization and so-called dekulakization. ${ }^{6}$

The importance of oscillating migrants working in the South African gold mines has been established in numerous studies; ${ }^{7}$ in Witbank's coalmines, too, by 1925 about 75 per cent of the miners were migratory workers from rural areas of Mozambique. These collieries produced coal mainly for the gold industry, and were often owned by goldmining companies. Mozambicans were recruited by the Witwatersrand Native Labour Association (WNLA, or "Wenela"), which had established a kind of monopoly to obtain mine and colliery labour from the Portuguese territory of Mozambique. The association had been created by the Chamber of Mines to provide the goldmines with cheap labour, but it also supported the Transvaal coal industry. In I920s over 80 per cent of African workers in the Witbank coalmining district were recorded as "Portuguese". They often had to be compelled to work in the collieries, especially in the years before World War I, as migrants favoured work in the goldmines. Although since I907 there had been a tendency among "detribalized" families to settle around the collieries, the proportion of "permanent" miners, permitted to live with their wives, was officially restricted in 1926 to is per cent. It seemed unlikely, however, that this percentage could be maintained. ${ }^{8}$

Also, in the Appalachian coalfields in West Virginia (United States), the great wave of black migrants from the South before and during World War I initially consisted of small peasants or sharecroppers. A significant percentage either owned farms in Virginia and North Carolina or had relatives who did. When work became irregular or wages declined substantially, they returned to these homes until work in West Virginia improved, often in a seasonal pattern. It was not until the I920s that they started to settle in coal towns, where semi-rural life was often maintained by miners' families, who cultivated gardens and raised livestock. ${ }^{9}$

6. Tanja Penter, Koble für Stalin und Hitler. Arbeiten und Leben im Donbass 1929-1953 (Essen, 2010), pp. 39-42.

7. T. Dunbar Moodie (with Vivienne Ndatshe), Going for Gold: Men, Mines, and Migration (Berkeley, CA, 1994); Ruth First, Black Gold: The Mozambican Miner, Proletarian and Peasant (Manchester, 1983); Alan Jeeves, Migrant Labour in South Africa's Mining Economy: The Struggle for the Gold Mines' Labour Supply I 890-1920 (Kingston, 1985); Jonathan Crush, "Migrations Past: An Historical Overview of Cross-Border Movement in Southern Africa", in David A. McDonald (ed.), On Borders: Perspectives on International Migration in Southern Africa (Kingston [etc.], 2000), pp. I 2-24.

8. Peter Alexander, "Oscillating Migrants, 'Detribalised Families' and Militancy: Mozambicans on Witbank Collieries, I918-1927”, Journal of Southern African Studies, 27 (2001), pp. 505-525, 507, 509, 517; idem, "Challenging Cheap-Labour Theory: Natal and Transvaal Coal Miners, ca.1 890-1950", Labor History, 49 (2008), pp. 47-70, 53-54.

9. Ronald L. Lewis, "From Peasant to Proletarian: The Migration of Southern Blacks to the Central Appalachian Coalfields", The Journal of Southern History, 55 (1989), pp. 77-102, 87-88. 


\section{MIGRATION AND LABOUR CONTRACTORS}

Where the distance between mine owners, managers, and migrant miners was large, systems of intermediation emerged, with a major role for labour contractors. They shaped both the recruitment and deployment of labour, and the systems of control inside and often outside the mines. Recruiting migrants using subcontractors seems to have been a common device in countries with underdeveloped labour markets and a rural population reluctant to enter the mines. During early industrialization, it was often difficult for large-scale enterprises to recruit sufficient numbers of miners, because labour markets were either non-existent or highly fragmented. The contractors had closer ties to the rural population than owners and managers did, and this made it easier for them to recruit labour from their home villages.

Subcontracting had been known in the British coal industry since the eighteenth century. It was associated with "controlling and maintaining an increasingly turbulent body of workmen", and described as "a form of organization peculiar to the adolescence of industrial society and destined to disappear as the British economy grew to maturity". ${ }^{\circ}$ Elsewhere in the world, the system was widely used to recruit and control both local and migrant labour. In Chinese coalmining, until the i 920 s the largest part of the labour force, up to between 60 and 80 per cent, was recruited by contractors, to work the coalface as well as to haul and tunnel underground. Apart from supplying labour, many contractors also had to provide most of the materials to work the mine. ${ }^{I}$ As Limin Teh makes clear in her article in this Special Issue, the large Japanese-owned Manchurian mines, however, incorporated labour contractors in their system of management and met severe shortages of labour in the I920s by sending their own agents to the Hebei and Shandong regions south of Manchuria, which formed an important reservoir of labour for these mines.

After 1907-1908 the use of labour contractors became widespread in South African goldmining for recruitment in South Africa itself (the supply of Mozambican labour was monopolized by WNLA). In many cases the labour contractor not only recruited, but also arranged transport, and fed and housed the worker after his arrival. ${ }^{\mathrm{I}}$ In her article in this Special Issue on the Enugu Colliery in Nigeria, Carolyn Brown shows how African

I0. Arthur J. Taylor, "The Sub-Contract System in the British Coal Industry", in Leslie S. Pressnell (ed.), Studies in the Industrial Revolution Presented to T.S. Ashton (London, I960), pp. 2 I 5-235, 229 and 234; for empirical qualifications, see James A. Jaffe, The Struggle for Market Power: Industrial Relations in the British Coal Industry, I 800-I 840 (Cambridge, I99 I), pp. 54-56. I I. Tim Wright, “'A Method of Evading Management': Contract Labor in Chinese Coal Mines before 1937”, Comparative Studies in Society and History, 23 (1981), pp. 656-678, 659, $663-665,669$.

I 2. Jeeves, Migrant Labour in South Africa's Mining Economy, pp. 97 and I53-183. 
"boss boys" were responsible for recruitment and discipline also beyond the workplace, in the labour camps where recruits from the villages were housed. Discipline was enforced by physical violence, extortion, and fines. ${ }^{13}$

In Indian coalmining large groups of migrant labour were recruited by labour contractors, engaged for the entire labour process, from the hiring of the labour force to the supervision of the cutting and loading of coal. At its lowest end, the system relied on gangmasters (so called sardars), who led groups of fifteen to forty miners, supervising work and receiving and distributing wages. The system was closely related to seasonal migration, as it enabled a stable but flexible connection between demand in the coalfields and supply in more or less remote villages. A contractor recruited relatives and personal friends from his home village or thereabouts, and made every effort to ensure that his "gang" would return to a particular mine next year. He advanced train fares, food, and money to his co-villagers, later to be deducted from wages earned, obliging workers to stay with him and to work at a particular colliery. ${ }^{\mathrm{I}}$ In this way mining companies were able to get a hold over the migratory labour force.

A similar recruiting system existed for the Russian seasonal miners in the Ukrainian Donbass. Agents (verbovshchiki) went to the villages to persuade peasants to work in the mines, paying their travel and living expenses. These advances were later deducted from wages, keeping the worker in debt from the beginning. Mostly, these recruiters also acted as artel'schick, the leader of a team (or artel') of up to thirty peasant miners, often friends and relatives from one village, who negotiated with the employers on behalf of the team, coordinated the work, and organized living arrangements. Much like his Indian counterpart, the contractor took responsibility for arranging for sufficient numbers of miners, and might provide horses for transport, and foremen and gang bosses to supervise daily work. He received the sum negotiated for piecework and in turn paid his workers by the shift. ${ }^{\mathrm{IS}}$ This kind of contracting ran counter to the aim of settling a permanent workforce, but it was the only way for the mining companies to recruit migratory workers from the land in sufficient numbers.

In Japan, too, a system of recruitment by labour contractors was generally used in coal and other mines. A contractor (known as hambagashira in the Hokkaido coalfields in the north and naya-gashira in Kyūshū coalfields in the south) hired several groups of between ten and twenty mineworkers from farming backgrounds, provided lodging, and supervised

I 3. See also Carolyn A. Brown, "We Were All Slaves": African Miners, Culture, and Resistance at the Enugu Government Colliery (Portsmouth, NH, 2003), pp. I I9-I 2 I.

14. Simeon, The Politics of Labour under Late Colonialism, pp. 27 and I49; Simmons, "Recruiting and Organizing an Industrial Labour Force", pp. 47 I-482.

I s. Friedgut, Iuzovka and Revolution, I, pp. 234, 260-263, and 269-27I. 
labour underground. On behalf of the mine owners the contractors had complete authority over the workforce, both at work and in daily life. They recruited the miners, supervised them at the production site, and controlled their life at their lodges. ${ }^{16}$ The system was a means to secure a regular supply of workers. In the southern Kyūshū coalfield the contracting system was also used to recruit families, to include females to work as haulers underground, but also at the surface. The system declined there only with the demise of female work in the underground teams after longwall mining had replaced pillar mining in the I920s. This in turn was made possible by the massive recruitment of Koreans, who were initially also recruited by Korean naya-gashira. ${ }^{17}$ Many of these Korean migrants returned to their home villages during the months of the summer harvest (July and August). ${ }^{18}$

\section{FORCED LABOUR}

The solutions employed by mine owners and the state to remedy the shortage of labour for the mines included various forms of compulsion or force. In this way the colliery owners were able to tie in a permanent supply of mining labour. In early modern Britain, systems of coercion were used to tie workers and their families to the mines, like the so-called "colliery serfdom" in eighteenth-century Scotland, and the "yearly bond" in the Durham mines. ${ }^{19}$

Systems of coercion of this kind were not confined to early modern Europe, however. In the coalfields of British India (Bengal), semi-feudal bonds were common in older collieries, in some cases even until the I950s. Mine owners there had purchased large tracts of land near the pits and had developed a service tenancy arrangement, whereby peasants were granted a small piece of land in return for working a certain number of days in the company mine instead of paying rent, on pain of eviction. ${ }^{20}$ In this way the

I6. On this "lodge system", both at the iron mines and the coalmines, see Nimura Kazuo, The Ashio Riot of 1907: A Social History of Mining in Japan (Durham, NC, 1997), pp. I6I-i78.

17. Yukata Nishinarita, “Technological Change and Female Labour in Japan”, UNU working paper (Tokyo, 1994), pp. 59-96; W. Donald Smith, "The I932 Asō Coal Strike: Korean-Japanese Solidarity and Conflict”, Korean Studies, 20 (1996), pp. 94-I 22, 96-98. On the early history and unevenness of Korean migration to the Kyūshū coalfield, see also the article by Tom Arents and Norihiko Tsuneishi in this Special Issue.

18. Michael A. Weiner, The Origins of the Korean Community in Japan, 19I0-23 (Atlantic Highlands, NJ, 1989), p. 66.

19. Alan B. Campbell, The Lanarkshire Miners: A Social History of their Trade Unions 1775-1874 (Edinburgh, 1979), pp. 9-I2; Sydney Webb, The Story of the Durham Miners (1662-I92I) (London, I92I), pp. 7-15; Thomas S. Ashton and Joseph Sykes, The Coal Industry of the Eighteenth Century (Manchester, 1929), pp. 70-99.

20. Simmons, "Recruiting and Organizing an Industrial Labour Force", pp. 463-47i; Simeon, The Politics of Labour under Late Colonialism, p. 26. 
colliery owners were able to tie in a permanent supply of mining labour. The system had been applied by early starters in the Indian coalfields; for more recently established enterprises, like in the Jahria coalfield, other means of obtaining the desired number of workers had to be used, mainly in the form of subcontracting migratory peasant miners (see above).

In this Indian example, and also in the case of the Zonguldak coalfield in Turkey, described by Kahveci in this issue, economic and extra-economic coercion were used to mobilize local labour for the mines. We find several examples, also in Chinese coalmining, well into the twentieth century, be it in the form of convict labour, debt servitude, or servile labour. ${ }^{2 \mathrm{I}}$ In other cases, force was used to bring in migrant labour. In colonial Zimbabwe (Southern Rhodesia), the Wankie Colliery (opened in 1902) relied heavily in its early years on so-called chibaro, indentured labourers supplied by the Rhodesia Native Labour Board. In I9I 840 per cent of the black labour force at the Wankie Colliery still belonged to this category, as against 60 per cent "voluntary" labour, often migrants passing on their way from Northern Rhodesia to South Africa, who would work at Wankie for several months before resuming their journey. Thereafter, structural changes in the labour market freed the Wankie Colliery more or less from chibaro labour: by 1927 the percentage had dropped to $5 .{ }^{22}$

In the Dutch East Indies (Indonesia), the labour shortage the Ombilin coalmines (West Sumatra) faced when they first began operating was "solved" by the forced employment of convict labourers, both political and criminal prisoners, from other parts of the colony. Their number fluctuated up to 2,400 in I 898. Later, Chinese and Javanese "contract labourers", too, were employed. They were not "free", but bound to work for several years under the complete jurisdiction of the mine. Convict and contract labourers dominated the growing number of miners until the first half of the I920s. After that, they gradually disappeared and were replaced by free labourers. ${ }^{23}$

Convict labour was, in fact, a fairly common recruitment device both in the start-up and the more advanced phases of coalmine development. In the nineteenth-century southern United States, convict labour drawn predominantly from among African Americans was regularly used in the coalmines of Georgia, Tennessee, and Alabama after the abolition of slavery

\footnotetext{
21. Tim Wright, Coal Mining in China's Economy and Society I895-I937 (Cambridge, 1984), p. 165 .

22. Ian Phimister, Wangi Kolia: Coal, Capital and Labour in Colonial Zimbabwe I894-1954 (Harare [etc.], I994), pp. I I and 76; see also on the Rhodesian gold mines, Charles van Onselen, Chibaro: African Mine Labour in Southern Rhodesia 1900-1933 (London, 1980), pp. 99 and I04-I I4.

23. Erwiza Erman, Miners, Managers and the State: A Socio-Political History of the Ombilin Coal-Mines, West Sumatra, I892-I996 (Amsterdam, I999), pp. 36-4I; idem, "Generalized Violence: A Case Study of the Ombilin Coal Mines, I 892-1996”, in Freek Colombijn and Thomas J. Lindblad (eds), Roots of Violence in Indonesia: Contemporary Violence in Historical Perspective (Leiden, 2002), pp. I05-I3I.
} 
(the employment of slaves had been common in the mines before). ${ }^{24}$ Well into the twentieth century, convict labour played a fundamental role in setting the conditions under which free miners laboured, and provided a steady source of labour. With many black miners staying after their release, their experience as convict labourers in fact prepared large numbers of blacks for the slightly less harsh regime they would endure as free miners. So, in I9ro over 50 per cent of black coalminers in the Birmingham (Alabama) district had learned their trade as convicts. In this way the system offered both an instrument for disciplining the black labour force and for securing a steady flow of cheap labour for the mines. ${ }^{25}$

In Japan, labour scarcity at the start of the Hokkaido and Kyūshū coalmines (from the I 880 s) was also solved in this way. Later on, convict labour was replaced by a system of recruitment by labour contractors (see above), but this system confined the freedom of the miners to such an extent that it could also be considered a form of forced labour. During World War I coalmining grew strongly because of the economic boom and it became difficult to procure more labour from the agrarian villages in Japan itself. As Arents and Tsuneishi show in this Special Issue, labour shortages were now solved by transferring Korean migrants from rural areas in colonized Korea. ${ }^{26}$ After 1939 the coercive mobilization of Koreans in the mines and other industries became increasingly important in the Japanese war economy. Between 1939 and 1945 more than 300,000 Koreans were sent to Japanese mines, most against their will. Koreans were almost exclusively used as underground face workers. In Hokkaido, for example, Koreans comprised over 40 per cent of the coalmining labour force, but they accounted for 60 to 70 per cent of underground workers. ${ }^{27}$ Some 40,000 Chinese prisoners of war were employed in the Japanese mines as well. ${ }^{28}$

24. Ronald L. Lewis, Black Coal Miners in America: Race, Class, and Community Conflict I780-1980 (Lexington, KY, 1987), pp. 3-I 2; Alex Lichtenstein, Twice the Work of Free Labor: The Political Economy of Convict Labor in the New South (London, 1996); and the article by Joe Trotter in this Special Issue.

25. Lewis, Black Coal Miners in America, pp. 33-34; Brian Kelly, Race, Class, and Power in the Alabama Coalfields, I908-2 I (Urbana, IL, 200I), pp. 90-94.

26. See also Yutaka Kusaga, Transfer and Development of Coal-Mine Technology in Hokkaido (Tokyo, 1982), pp. 24-26, 39-42, and 59-64; Weiner, The Origins of the Korean Community, ch. 3; Ken C. Kawashima, The Proletarian Gamble: Korean Workers in Interwar Japan (Durham, NC, 2009), pp. 25-45; Regine Mathias, Industrialisierung und Lohnarbeit. Der Koblebergbau in Nord-Kyüshü und sein Einfluss auf die Herausbildung einer Lohnarbeiterschaft (Vienna, 1978), pp. I 59-162; Michael Weiner, Race and Migration in Imperial Japan (London [etc.], 1994), pp. II $2-113$, I $33-135$, and I 50 .

27. Weiner, Race and Migration in Imperial Japan, p. 205; W. Donald Smith, "Beyond The Bridge on the River Kwai: Labor Mobilization in the Greater East Asia Co-Prosperity Sphere", International Labor and Working-Class History, 58 (2000), pp. 21 9-238, 223-226.

28. Laura E. Hein, Fueling Growth: The Energy Revolution and Economic Policy in Postwar Japan (Cambridge, MA, I990), pp. 35-4I. 
Convict labour and other forms of forced labour were also introduced in the newly built Kuzbass basin in Siberia to meet the demands of forced industrialization in the Soviet Union in the I930s, as Julia Landau details in her contribution to this Special Issue. In the German Ruhr, forced migrant labour, both civilian workers and prisoners of war, had already been used during World War I. These were mainly Belgians and Poles from the occupied Russian territories (at that time Poland did not exist as an independent state). ${ }^{29}$ The experience with this kind of Arbeitseinsatz during World War I prepared the ground for the development of an extensive system of forced labour to support the war economy of Nazi Germany during World War II, both in Germany itself and in the European occupied territories. ${ }^{3 \circ}$ In this system, ethnic discrimination and forced labour were closely interrelated as most of the deployed workers were so-called Ostarbeiter and prisoners of war from Poland, Ukraine, and Russia, and were considered by the Nazis to be of an inferior "race".

\section{BRITISH AND OTHER MINERS IN WHITE SETTLER COLONIES IN THE EMPIRE}

Much of the global expansion of coalmining in the nineteenth and twentieth centuries was possible only because of the migration of skilled groups of workers from Great Britain. They introduced mining skills and techniques, and often continued to hold privileged positions afterwards. The migration trajectories of British miners can be traced in almost every coalfield in the British Empire, but also in other parts of the world. One example is described by Clarice Speranza in this Special Issue in relation to the beginnings of coalmining in Brazil. In the Ukrainian Donbass (Donets basin) the first mines were opened in I 869 by the Welsh investor John J. Hughes (the place Juzovka was named after him), and he took some roo Welsh and English workers with him. ${ }^{3 \mathrm{I}}$ Another example: in the early twentieth century the American-based Arctic Coal Company developed coalmining in the remote Spitsbergen Islands using experienced English miners from Sheffield. Common labourers were recruited in Norway (and also brought a habit of frequent strikes). ${ }^{32}$

29. Kai Rawe, “... wir werden sie schon zur Arbeit bringen!”. Ausländerbeschäftigung und Zwangsarbeit im Rubrkoblenbergbau während des Ersten Weltkrieges (Essen, 2005).

30. Klaus Tenfelde and Hans-Christoph Seidel (eds), Zwangsarbeit im Bergwerk. Der Arbeitseinsatz im Kohlenbergbau des Deutschen Reiches und der besetzten Gebiete im Ersten und Zweiten Weltkrieg, Band I: Forschungen (Essen, 2005). For the Belgian and French cases see also Nathalie Piquet, Charbon-Travail forcé-Collaboration. Der nordfranzösische und belgische Bergbau unter deutscher Besatzung, 1940 bis 1944 (Essen, 2008).

31. Theodore H. Friedgut, Inzovka and Revolution, II: Politics and Revolution in Russia's Donbass, I869-I924 (Princeton, NJ, I994), p. I9.

32. Seth C. DePasqual, "Winning Coal at $78^{\circ}$ North: Mining, Contingency and the Chaîne Opératoire in Old Longyear City" (MA thesis, Michigan Technological University, 2009), p. 28, 
With the global expansion of coalmining from the nineteenth century onwards, British miners moved from coalfield to coalfield in British settler colonies such as South Africa, Canada, Australia, and New Zealand to develop the industry there. In the South African coalmines of Natal and Transvaal a high proportion of senior staff was Scottish; others came from Wales, Northumberland, Cornwall, and elsewhere in Britain. ${ }^{33}$ In Australia, the coalfields of the Newcastle district in New South Wales were populated by English and Scottish miners, who also brought their tradition of trade unionism. ${ }^{34}$ In the twentieth century Scottish migrants were still prominent in the Australian coalfields. ${ }^{35}$ The West Coast mining district of New Zealand was an enclave of British mining practice as well. British colliers from Scottish and English coalfields had often first arrived in Australia. ${ }^{36}$

Also in the Canadian coalfields, both in the east (Nova Scotia) and the west (Vancouver Island), the British were the first to develop a mining industry and continued to arrive afterwards. Industrial mining in Nova Scotia started in the 1840 s with experienced miners from Britain, who were later to form the higher strata of a hierarchy within the workforce. ${ }^{37}$ The rapid expansion of the coal industry after 1900 brought a flood of new people into the area from other parts of Canada, the United States, the British Isles, France, eastern Europe, and elsewhere, but miners of Scottish descent continued to play an important role. ${ }^{38}$

Early recruitment of colliers for the coalmines on Vancouver Island started in 1854 from Staffordshire in England. As a result of chain migration their numbers swelled, with migrants being attracted from other British coalfields too. Soon, the whole of the British Isles were represented. Many "worked their way" through mining jobs in several colonies and

available at http://digitalcommons.mtu.edu/cgi/viewcontent.cgi 3 article $=1307 \&$ context $=$ etds, last accessed 3 August 2015 .

33. Alexander, "Challenging Cheap-Labour Theory", p. 51; Peter Alexander, "Race, Class, Loyalty and the Structure of Capitalism: Coal Miners in Alabama and the Transvaal, I91 8-1922", Journal of Southern African Studies, 30 (2004), pp. I I 5-1 32, I 19 n. 20.

34. Ellen McEwen, "Coalminers in Newcastle, New South Wales: A Labour Aristocracy?”, in Eric Fry (ed.), Common Cause: Essays in Australian and New Zealand Labour History (Sydney, NSW, I986), pp. 77-92, 79-80; Robin Gollan, The Coalminers of New South Wales: A History of the Union, I860-1960 (Melbourne, VIC, 1963), pp. I7-19.

35. Andrew Reeves, “Damned Scotsmen': British Migrants and the Australian Coal Industry, 1919-49”, in Fry, Common Cause, pp. 93-106.

36. Len Richardson, "British Colliers and Colonial Capitalists: The Origins of Coalmining Unionism in New Zealand", in Fry, Common Cause, pp. 59-75; Len Richardson, Coal, Class E Community: The United Mineworkers of New Zealand, I880-1960 (Auckland, I995), pp. 3-28. 37. Del Muise, "The Making of an Industrial Community: Cape Breton Coal Towns, I 867-I900", in Don Macgillivray and Brian Tennyson (eds), Cape Breton Historical Essays (Sydney, Cape Breton Island, I98 I), pp. 76-94.

38. Paul MacEwan, Miners and Steelworkers: Labour in Cape Breton (Toronto, 1976). 
countries of the Anglo-Saxon world. The British-born miners retained their prominence over the years. In I 88 I the British colliers represented 79 per cent of the white workforce in the main Vancouver Island mining town of Nanaimo; in I89I this was still 6r per cent. The other whites were from a variety of other countries (from Walloon Belgium, among others), or had been born in Canada itself. ${ }^{39}$

Unskilled, casual labour on Vancouver Island was at first recruited from the native population, providing an auxiliary source of labour, but from the I 870 s the aboriginals were increasingly displaced by Chinese migrants. The Chinese performed mining tasks that were looked upon as humiliating by white miners. Efforts were repeatedly made to exclude Asian labour, but the Chinese remained a critical part of the collieries' workforce into the twentieth century, both above and below ground. The Chinese were employed especially in longwall mines, where craft labour had been replaced by semiskilled labour, under the supervision of a small number of whites. ${ }^{40}$ White miners of British descent opposed the recruitment of Chinese labour, not only out of racial prejudice, but also in defence of craft positions. ${ }^{4 \mathrm{I}}$

The South African sociologist John Hyslop has made a case for treating white workers of British origin in the settler colonies of the Empire as part of an "imperial working class" for which "whiteness" was a core component of identity. ${ }^{42}$ This view is only partially convincing, as there were also British immigrants in South Africa, Canada, and Australia, who brought radical socialist and later communist ideas to the colonial coalfields and propagated interracial solidarity. ${ }^{43}$ More importantly, without suggesting

39. John Belshaw, Colonization and Community: The Vancouver Island Coalfield and the Making of the British Columbian Working Class (Montreal, 2002), pp. 40 and 52-54, 59-60; idem, "The British Collier in British Columbia: Another Archetype Reconsidered", Labour/Le Travail, 34 (1994), pp. I I-36; Allen Seager and Adele Perry, "Mining the Connections: Class, Ethnicity, and Gender in Nanaimo, British Columbia, 1891", Histoire Sociale/Social History, 30 (1997), pp. 55-76, 67-69, and 73. Belgian miners were particularly active in the great miners' strike of $\mathrm{I} 89 \mathrm{I}$ in Nanaimo: ibid., p. 59.

40. Belshaw, Colonization and Community, pp. i 17-1 22.

41. Idem, "The British Collier in British Columbia", p. 35 .

42. Jonathan Hyslop, "The Imperial Working Class Makes Itself 'White': White Labourism in Britain, Australia, and South Africa before the First World War", Journal of Historical Sociology, I 2 (I999). pp. 398-42 I.

43. Neville Kirk, "The Rule of Class and the Power of Race: Socialist Attitudes to Class, Race and Empire", in idem, Comrades and Cousins: Globalization, Workers and Labour Movements in Britain, the USA and Australia from the I880s to 1914 (London, 2003), pp. I49-238; William Kenefick, "Confronting White Labourism: Socialism, Syndicalism, and the Role of the Scottish Radical Left in South Africa before 1914", International Review of Social History, 55 (2010), pp. 29-62; Jonathan Hyslop, "Scottish Labour, Race, and Southern African Empire c. r 880-1922: A Reply to Kenefick", International Review of Social History, 55 (2010), pp. 63-8 I; Lucien van der Walt, "The First Globalisation and Transnational Labour Activism in Southern Africa: White 
that there was no racism involved, the opposition of white British miners to the entry of other ethnic and racial groups was inextricably linked to the defence of craft and skill in the mining industry.

\section{AND IN THE UNITED STATES}

The transfer of experience and technological skills, acquired at the coalface in the British mines, was essential for the development of the mining industry in the United States as well. The migration of British coalminers to the United States reached a provisional high in the 1860 s and the early I 870 s. In I 870 British immigrant miners (57,2 I4) accounted for more than 60 per cent of all foreign-born miners $(94,719)$ in the country. Once arrived, they moved from coalfield to coalfield in different US states. In Britain, emigration was sponsored by trade unions to reduce excess labour at British mines. Miners' leaders co-operated with agents, not only for American, but also for Nova Scotian (Canadian), New Zealand, and Australian coal companies in their recruitment efforts in England, Scotland, and Wales. Often British miners became union organizers in United States coalmining, and stayed in close contact with fellows and unions "at home". ${ }^{44}$

Many of these immigrant miners were young single men who travelled from mine to mine on a seasonal basis. Arriving with cheap tickets for the summer season, they would return to Britain for winter work, or travel a miners' circuit through different mining states. Depressions, like that of I 873, drove recently arrived migrant colliers back to their former homes in Britain. In this way transatlantic immigrant networks became conduits of British influence in American mining practices, not least in trade unionism. ${ }^{45}$ Up to 1900 , British-born immigrants were still dominant in coalmining in Illinois, Pennsylvania, West Virginia, and Kansas. Native-born miners were often also of British descent. Like everywhere else, ethnic networks were important in the migration patterns of British miners. ${ }^{46}$ Welsh miners tended to cluster in communities around their own churches and to intermarry in their own group. ${ }^{47}$ Welsh mine owners and managers often selected other

Labourism, the IWW, and the ICU, 1904-1934”, African Studies, 66 (2007), pp. 223-25 I; Bill Freund, "Labour Studies and Labour History in South Africa: Perspectives from the Apartheid Era and After", International Review of Social History, 58 (2013), pp. 493-519, 500-501.

44. Amy Zahl Gottlieb, "Immigration of British Coal Miners in the Civil War Decade", International Review of Social History, 23 (1978), pp. 357-375.

45. John H.M. Laslett, "British Immigrant Colliers, and the Origins and Early Development of the UMWA, I870-1912", in idem (ed.), The United Mine Workers of America: A Model of Industrial Solidarity? (University Park, PA, 1996), pp. 29-50, 30-3 I.

46. Idem, Colliers Across the Sea: A Comparative Study of Class Formation in Scotland and the American Midwest, $1830-1924$ (Urbana, IL [etc.], 2000).

47. Ronald L. Lewis, Welsh Americans: A History of Assimilation in the Coalfields (Chapel Hill, NC, 2008), p. 8. 
Welshmen for their mining staff and workforce, thereby creating ethnic Welsh settlements. ${ }^{4}$

At the end of the nineteenth century, Italians, "Slav", and other migrants from southern and eastern Europe increasingly started to work in the coalmines of the United States. By 1900 the combined total of Austro-Hungarians, Poles, and Russians in the anthracite mines of Pennsylvania had reached $3 \mathrm{I} \cdot 3$ per cent. Other mining districts, especially in the northern states, followed. The "Slav" and Italian migrant miners were mostly of peasant origin and unskilled. Their working in the mines went hand in hand with the introduction of coal-cutting machines and the deskilling of mine work. The proportion of British miners diminished, but they kept a position as foremen and skilled workers. A I9I0 visitor to the Pennsylvania anthracite region summarized the resulting ethnic hierarchy: "Managers and superintendents: Welsh; foremen and bosses: Irish; contract miners: Poles and Lithuanians; outside laborers: Slovaks, Ruthenians, and Italians." 49 Welsh preponderance in supervisory roles was common throughout the coal industry prior to World War I. The Irish, "Slav", and Italian miners generally acted as labourers with a lower status. In these hierarchies social and ethnic differences went together. ${ }^{50}$ However, despite the condescending attitude that Anglo-Saxon miners displayed towards the "new European" immigrants, ${ }^{5 \mathrm{I}}$ eastern European and Italian migrants soon took an active part in the miners' struggles and had to be accepted as members in the miners' union branches. ${ }^{52}$

Joe Trotter, in his contribution to this Special Issue, offers an overview of ethnic and race relations in the American coal industry and shows that relationships between "white" and African-American miners in trade unionism were much more ambivalent. While there were several coalmining districts, in Alabama for instance, where British miners participated in interracial unions, ${ }^{53}$ the racial policies of organized labour were far from uniform. A debate on black workers, race, and organized labour in the United States, referred to as the "Gutman-Hill debate", ${ }^{54}$ started several

48. Idem, "Networking among Welsh Coal Miners in Nineteenth-Century America", in Stefan Berger, Andy Croll, and Norman LaPorte (eds), Towards a Comparative History of Coalfield Societies (Aldershot, 2005), pp. 191-203.

49. Quoted in Laslett, "British Immigrant Colliers", pp. 46-47.

50. Lewis, Welsh Americans, pp. I 89-249.

5. See also Michael A. Barendse, "American Perceptions concerning Slavic Immigrants in the Pennsylvania Anthracite Fields, r880-19ro: Some Comments on the Sociology of Knowledge”, Ethnicity, 8 (1981), pp. 96-105.

52. Laslett, "British Immigrant Colliers", p. 49; see also Mildred A. Beik, "The UMWA and New Immigrant Miners in Pennsylvania Bituminous: The Case of Windber”, in Laslett, The United Mine Workers of America, pp. 320-344.

53. Alexander, "Race, Class, Loyalty and the Structure of Capitalism", pp. i i 8 and I 26.

54. Alex Lichtenstein, "Herbert Hill and the 'Negro Question"”, Labor: Studies in Working-Class History of the Americas, 3:2 (2006), pp. 33-39. See also Joe William Trotter, Coal, Class, and 
decades ago. It has continued in extended discussions about the importance of "whiteness" in American working-class history, especially after publication of David Roediger's The Wages of Whiteness in I991.5

Price Fishback explained the difference in the experiences of AfricanAmerican miners in the American coalfields in relation to racial discrimination and assimilation by the tightness or looseness of labour markets there. African Americans did better in the Alabama and West Virginia labour markets, because employers were constantly seeking new workers, and black migrants found ample employment. This contrasted with coalfields further north, where limits on employment growth constrained AfricanAmerican immigration. ${ }^{56}$ In West Virginia a large number of black miners worked side by side with other ethnic groups and were easily accepted into the miners' union, the United Mine Workers of America.

Fishback relates the arrival of different migrant groups in the United States mines to different phases of exploitation: most British immigrants came with coalmining experience and helped train American workers. They played a major role in the early development of the United States coal industry in the mid-I 800 s. Later, in the I 880 s, and even more so between I 890 and I9I0, in the Pennsylvania and Midwest mining regions inexperienced immigrants from eastern and southern Europe were employed on a massive scale to fill the need for unskilled labour. The coalfields in the low-wage Southern states (Kentucky, Virginia, West Virginia, Alabama) in turn attracted more African-American workers, migrating north from the Deep South.

\section{THE POLISH DIASPORA IN EUROPE AND THE UNITED STATES}

The Poles were the first and initially the most mobile among migratory mineworkers in Europe. From the last few decades of the nineteenth century they were mobilized on a massive scale to work in the coalmines of the Ruhr in Germany. ${ }^{57}$ Polish migration to the Ruhr started in the I 870 s

Color: Blacks in Southern West Virginia, I9I5-32 (Urbana, IL, I990); Daniel Letwin, The Challenge of Interracial Unionism: Alabama Coal Miners, I878-I92 I (Chapel Hill, NC, I998); Kelly, Race, Class, and Power, pp. 6-is and i 8-i 22.

55. David R. Roediger, The Wages of Whiteness: Race and the Making of the American Working Class (New York, 1991). For a review, see Eric Arnesen, "Up from Exclusion: Black and White Workers, Race, and the State of Labor History", Reviews in American History, 26 (1998), pp. I 46-174; Bruce Nelson, "Class, Race and Democracy in the CIO: The 'New' Labor History Meets the 'Wages of Whiteness', International Review of Social History, 4I (I 996), pp. 35 I-374. 56. Price V. Fishback, Soft Coal, Hard Choices: The Economic Welfare of Bituminous Coal Miners, I 890-1930 (New York [etc.], I992), pp. I71-197.

57. Christoph Kleßmann, Polnische Bergarbeiter im Rubrgebiet I 870-1945. Soziale Integration und nationale Subkultur einer Minderheit in der deutschen Industriegesellschaft (Göttingen, 1978); John J. Kulczycki, The Foreign Worker and the German Labor Movement: Xenophobia 
with the recruitment of skilled miners from Upper Silesia (then still part of the German Empire), where coalmining had a much longer history. In the expansion phase following this initial immigration, however, most of the Polish migrants were unskilled workers, recruited from agricultural areas in West and East Prussia. At that time, almost all of them were Prussian citizens. By I9Io, at least one-quarter of all Ruhr miners were Polish-speaking. Having arrived in the Ruhr, they formed ethnic communities, based on social organizations such as churches, trade unions, a Polish press, and sports clubs. As Diethelm Blecking reports in his article on Polish miners and sport in this Special Issue, the confrontation with a foreign and often hostile German milieu helped to foster a common national identity among these migrants, who had hitherto a locally oriented peasant background.

After World War I Poles from the Ruhr and from Poland itself moved to coalfields in northern France, ${ }^{58}$ and to a lesser extent in Belgium and the Netherlands. ${ }^{99}$ In the I 920 s the number of Poles in the Ruhr was reduced to nearly one-third through re-migration and onward migration. For both economic and political reasons, many Polish workers from the Ruhr had moved to those mining areas in northern France that were suffering from a shortage of labour just after World War I. ${ }^{60}$ As Philip Slaby makes clear in his article in this Special Issue, the German-Polish migrants, called "Westphaliens", brought a Polish press, social clubs, societies, and other organizations to France, and in this way were able to hold on to a Polish ethnic, religious, and national identity in a rather conservative fashion. This ethnicized segregation was consciously promoted by the mining companies, which sought both a fragmented workforce and ideologicalcultural means to curb labour militancy.

and Solidarity in the Coal Fields of the Rubr, 187 IIIII $_{4}$ (Providence, RI, 1994); idem, The Polish Coal Miners' Union and the German Labor Movement in the Ruhr, 1902-1934: National and Social Solidarity (Oxford, 1997); Richard C. Murphy, Gastarbeiter im Dentschen Reich: Polen in Bottrop I 891-1933 (Wuppertal, 1982), also in English: Guestworkers in the German Reich: A Polish Community in Wilhelmian Germany (New York, I983); Wolfgang Köllmann, "Les mouvements migratoires pendant la grande période d'industrialisation de la Rhénanie-Westphalie”, Annales de Démographie Historique, (197I), pp. 91-I 20.

58. Christoph Klessmann, "Comparative Immigrant History: Polish Workers in the Ruhr Area and the North of France", Journal of Social History, 20 (1986), pp. 335-353; Janine Ponty, Polonais méconnus. Histoire des travailleurs immigrés en France dans l'entre-deux guerres (Paris, 1988); Philip H. Slaby, Industry, the State, and Immigrant Poles in Industrial France, 1919-I939 (Ann Arbor, MI, 2005).

59. Pien Versteegh, De onvermijdelijke afkomst? De opname van Polen in het Duits, Belgisch en Nederlands mïnbedrijf in de periode 1920-1930 (Hilversum, 1994).

60. Donald Reid, "The Limits of Paternalism: Immigrant Coal Miners' Communities in France, I919-45", European History Quarterly, is (1985), pp. 99-1 I 8, I00; Gary S. Cross, Immigrant Workers in Industrial France: The Making of a New Laboring Class (Philadelphia, PA, 1983), pp. $8 \mathrm{I}-84$. 
As both employers and the French state were interested in recruiting Polish workers, a bilateral treaty was signed in I9I 9 to regulate the arrival of Polish citizens to the mines. This "Convention entre la France et la Pologne relative à l'émigration et l'immigration" can be considered the first in a system of state-regulated migration of mineworkers in Europe (see below). The employers cooperated in a Société Générale d'Immigration, which undertook a "systematic programme of prospecting" in Poland. ${ }^{6}$ This resulted in a new wave of Polish outmigration of workers of peasant origin. Between 1920 and 1930 a total of 490,000 Polish migrants came to France, while about 60,000 left. A climax was reached in 1929 and 1930 . The depression of the I930s led to the expulsion of many of the Polish migrants who had arrived during the boom period in the 1920s. After 1937, when the French economy started to recover, the number of immigrant Poles rose again. Almost all migrants (92 per cent in Nord-Pas-de-Calais) worked in underground positions, while supervisory personnel were mostly French. ${ }^{62}$ After World War II, however, the Poles left the French mines en masse, be it to their home country or to other jobs: while there had been 46,000 miners of Polish descent in I946, there were only 283 in $198 \mathrm{I}^{6}{ }^{63}$

The new migrants arriving directly from Poland were more susceptible to social radicalization and rapprochement with the French labour movement than the Westphaliens. Some of the direct immigrants copied the Westphaliens' example and joined Polish clubs and societies; others adhered to French left-wing trade unions, and formed a Polish section of the Communist Party. In the r 930 s a process of "depolonization" can be noticed. In the Popular Front period, communist influence among Polish immigrants reached its peak. In I937, the circulation of the Polish-language newspaper issued by the Polish section of the PCF rose to $35,000 .{ }^{64}$ Some authors consider the participation of Polish immigrant workers in French trade unions "to have contributed strongly to bringing together immigrant and French workers by treating them as equals". ${ }^{5}$

The first Polish mineworkers arrived in Belgium, at the Hainaut mines, before World War I. In the early i920s Poles from the Ruhr and northern France also moved to the Belgian mines. In 1922 Belgian coal owners started to recruit in Poland itself. The number of immigrant Poles grew to several

61. Reid, “The Limits of Paternalism”, p. I02; Cross, Immigrant Workers in Industrial France, pp. $55-63$.

62. Ponty, Polonais méconnus, pp. 69-72; Klessmann, "Comparative Immigrant History", pp. $337-338$.

63. Rolande Trempé, "La politique de la main-d'oeuvre de la Libération à nos jours en France", Revue Belge d'Histoire Contemporaine, 19 (1988), pp. 55-82, 70.

64. Klessmann, "Comparative Immigrant History”, pp. 34I-347; Reid, "The Limits of Paternalism”, pp. IO6-III.

65. Cited by Reid, “The Limits of Paternalism”, p. i I I. 
hundred each year. Individual migration developed alongside organized recruitment. In September 1930 there were I I,993 Polish mineworkers in Belgium. In the depression years several thousand miners were dismissed again and had to return to Poland, but economic recovery in 1937 enabled a new recruitment campaign. ${ }^{66}$ In the Netherlands, Poles had already begun to arrive before World War I as well, be it in relatively small numbers. Most of them came from the Ruhr. After World War I Dutch mining companies sent agents to the Ruhr and also to northern France to recruit Poles there. In the second half of the I920s they started to recruit directly in Poland and in other countries in central, eastern, and southern Europe. As in Belgium, in the wake of official recruitment Polish migrants travelled from mine to mine in Germany, Belgium, and France. At its highest point there were some I,200 Poles working in Dutch mines. ${ }^{67}$

Initially, the origin of Polish migration to the Ruhr and the Pennsylvanian anthracite region in the United States was quite similar. In the I870s, both migrant groups tended to come from traditional mining areas in Upper Silesia. By the I 890 , however, the regions of origin were diverging sharply. In the Ruhr, almost all Polish migrants came from the German rural provinces of East Prussia, and because of the rapidly growing demand for labour in the Ruhr the number of Poles from the Prussian provinces migrating to the Pennsylvania coalfields decreased. The majority of Polish migrants to the United States now came from the Austrian (Galicia) and Russian empires. ${ }^{68}$

Both in the Ruhr and in Pennsylvania the Poles were the most numerous part of a highly diversified workforce in the mines. By 1914, at least twenty different languages were spoken in the Ruhr by migrants from the Netherlands, Belgium, and different parts of the Russian, Austrian, and German empires. Germans with local or regional roots had the highest status. In Pennsylvania "old" migrants from Great Britain and Ireland and their American-born children constituted the core of the "native" workforce, continuing to occupy the jobs with the highest status. In both regions, recently arrived Poles generally possessed the lowest social standing, at least until other immigrants began to arrive from the I 890 on; they suffered from significant discrimination because of their "foreign" language, religion, habits, and peasant background. ${ }^{69}$ As a reaction, Poles

66. Frank Caestecker, Alien Policy in Belgium, 1840-1940: The Creation of Guest Workers, Refugees and Illegal Aliens (New York [etc.], 2000), pp. 47, 60, 67-68, 92-94, I 17-I 23, I76-I 82, $216-225$, and $243-345$.

67. Serge Langeweg, Mijnbouw en arbeidsmarkt in Nederlands-Limburg. Herkomst, werving, mobiliteit en binding van mïnwerkers tussen 1900 en 1965 (Hilversum, 20I I), pp. I29-130, I $40-148$, and I 53 .

68. Brian McCook, The Borders of Integration: Polish Migrants in Germany and the United States, $1870-1924$ (Athens, OH, 20I I), pp. 20-2 I.

69. Ibid., p. 25 . 
developed an outspoken ethnic identity, supported by organized sociability. In pre-I9I4 Germany Poles established their own union, the Zjednoczenie Zawadowe Polski [Polish Trade Union], but in Pennsylvania they soon became involved in the undifferentiated United Mine Workers of America. ${ }^{70}$

\section{STATE-REGULATED LABOUR MIGRATION \\ TO NORTH-WESTERN EUROPE}

Shortages of labour in several continental western European coalfields had already emerged in the expansion years before World War I, and they re-emerged after that war and in the I920s. While in that period Great Britain and Germany were able to build a mining labour force from their own internal labour supply, France, Belgium, and the Netherlands witnessed severe labour shortages. To counteract these labour shortages in the interwar years, not only in the mining industry, western European countries developed systems of regulated migration based on bilateral treaties, especially with newly formed states in eastern Europe such as Poland, Yugoslavia, and Czechoslovakia, but also with Italy. These agreements set up official migration channels alongside spontaneous individual migration. State involvement was triggered by protectionist labour-market policies, increasing state involvement in welfare arrangements, and the concomitant costs of unregulated migration for both employers and the state. ${ }^{71}$

As mentioned above, the immigration agreement concluded between France and Poland on 7 September I9I9 can be considered the first in a series of treaties of this kind. It was very soon followed, on 30 September, by a treaty with Italy, which in the early i920s brought a first wave of Italian migrants to the coalfields in northern and central France, mainly from central and north-eastern Italy. ${ }^{72}$ Belgium concluded an agreement with Italy to regulate migration in $1923 .{ }^{73}$ In general, the Belgian state cooperated closely with employers' organizations in the mines, and this was also the case in the recruitment of smaller numbers from Czechoslovakia,

70. Ibid., pp. 70-93.

7I. Christoph Rass, "Temporary Labour Migration and State-Run Recruitment of Foreign Workers in Europe, 1919-1975: A New Migration Regime?”, International Review of Social History, 57 (2012), pp. I9I-224; idem, Institutionalisierunsprozesse auf einem internationalen Arbeitsmarkt: Bilaterale Wanderungsverträge in Europa zwischen 1919 and 1974 (Paderborn [etc.], 2010).

72. Rudy Damiani, "Les Italiens: une immigration d'appoint", in Marie Cegarra et al., Tous gueules noires. Histoire de l'immigration dans le bassin minier du Nord-Pas-de-Calais (Lewarde, 2004), pp. 8 5-I09; Rudy Damiani, "Les Italiens du bassin miner du Nord-Pas-de-Calais de 1939 à I945", in Pierre Milza and Denis Peschanski (eds), Exils et migration. Italiens et Espagnols en France, $1938-1946$ (Paris, 1994), pp. 455-464.

73. Caestecker, Alien Policy in Belgium, pp. 62-65. 
Yugoslavia, Hungary, and Poland. ${ }^{74}$ In the Netherlands, in the second half of the I920s the organized recruitment of foreign workers in their home countries replaced previous attempts to attract skilled migrants from the coalfields of the Ruhr and Nord-Pas-de-Calais. Recruitment campaigns by Dutch mining companies in Czechoslovakia, Yugoslavia, Poland, and Italy brought new groups of inexperienced migrant workers to the coalmines. The campaigns were organized jointly by employers' organizations, state officials, and institutions in the countries of origin, on the basis of bilateral agreements. However, during the depression of the I930s most of the newly arrived migrants were dismissed and sent home. ${ }^{75}$

After World War II the system of bilateral migration agreements became a general device to recruit "guestworkers" for the north-west European mining industry from Mediterranean countries. It all started with Italy. Just after the war, urgent energy needs, both in France and Belgium, prompted governments to call for a bataille de charbon (a "battle for coal"), but labour supply in these countries fell short. Italy became the preferred country for the recruitment of migrant labour for the mines in France, Belgium, and somewhat later also in the Netherlands. In spite of attempts by Italy to include their citizens in the guidelines for the free movement of workers by the European Coal and Steel Community (I95I and 1957), national states held on to separate recruitment agreements. ${ }^{76}$ France concluded an agreement with Italy on 26 February 1946 to arrange for the arrival of migrants in exchange for the delivery of a fixed amount of coal to Italy for each miner. ${ }^{77}$ At first 20,000 were recruited. After November 1946 some 200,000 followed; most of them left again after the expiration of their contracts, however. Several new waves of Italians arrived in the I950s. The employment of Italians in French coalmining rose to a highpoint of I I,023 in 1958 ; thereafter their number diminished to 1,687 in $198 \mathrm{I}^{78}$

A few months later than France, on the 20 June 1946, Belgium concluded a comparable agreement with Italy on the recruitment of (initially) 50,000 miners, and a yearly (paid) export of 2 to 3 million tons of Belgian coal to Italy. Between 1946 and I958 I4I,I5 I Italians were officially recruited to work in the mines, but this figure does not include the unorganized, spontaneous migration of individuals, arriving with the help of family members or acquaintances, whose number must have been considerable as well. As in France, because of the enormous turnover of

74. Ibid., pp. $22 \mathrm{I}-222$.

75. Langeweg, Mijnbouw en arbeidsmarkt, pp. I44-1 50.

76. Simone A.W. Goedings, Labor Migration in an Integrating Europe: National Migration Policies and the Free Movement of Workers, 1950-1968 (The Hague, 2005), pp. 60-6I, 91-93, and 3I $2-3$ I3.

77. Damiani, "Les Italiens", pp. 97-98.

78. Trempé, “La politique de la main-d'oeuvre”, p. 70. 
migrants a large difference arose between numbers recruited and those actually working at the end of each year. ${ }^{79}$ The movement into and out of Belgian coalmines amounted to about one-third of the total number of underground miners in 1955-1956, twice the rate in France or Germany. Nevertheless, in Belgium the number of Italians working in the mines was much larger than in France: between 1948 and 1957 it fluctuated between 33,000 and 47,500 at the end of each year. After the Marcinelle disaster in I956, which killed 269 miners, among them I 36 Italians, the number of Italians employed in Belgian coalmines diminished from 44,000 in 1957 to 2,500 in $1975 .{ }^{80}$ The Netherlands was a relative latecomer in the interstate quest for migrant workers from Italy: on 4 December 1948 an agreement was signed with the Italian government to recruit for the coalmines, although on a much smaller scale than in the French or Belgian cases: ${ }^{8 \mathrm{I}}$ in I 957 the number of Italians had risen to only I,966.

The proliferation of these kinds of agreement for the state-sponsored recruitment of migrant workers has to be considered a response to shortages of unskilled or semiskilled labour in the mines. ${ }^{82}$ Demand for unskilled labour had increased, relatively at least, because of the introduction of new mining methods and technologies. The Italian migrants were recruited mainly from the agrarian central and southern parts of the country, had no earlier experience with minework, and had to learn the skills on the job. This is one explanation for the high turnover, other explanations being the miserable conditions of their lodgings (often camp-like dwellings), poor working conditions, and their status as subordinate workers in general. As soon as new opportunities arose in their home country, the migration flow from Italy dried up. Western European countries started to negotiate with other countries in the Mediterranean periphery to find new supplies of mine labour. Instead of Italy, in the r96os Spain, Yugoslavia, Greece, Tunisia, Turkey, and Morocco became preferred countries of recruitment for the coal and other industries in continental western Europe. This time, Germany, too, joined the group of recruiting countries. From each of these countries,

79. Anne Morelli, "L'appel à la main d'oeuvre italienne pour les charbonnages et sa prise en charge à son arrivée en Belgique dans l'immédiat après-guerre", Revue Belge d'Histoire Contemporaine, XIX (1988), pp. 83-I 30.

80. René Leboutte, "Coal Mining, Foreign Workers and Mine Safety: Steps towards European Integration, 1946-85", in Berger et al., Towards a Comparative History of Coalfield Societies, pp. $219-237,228-230$.

$8 \mathrm{I}$. Tesseltje de Lange, Staat, markt en migrant. De regulering van arbeidsmigratie naar Nederland 1945-2006 (Amsterdam, 2007), pp. 69-70; Langeweg, Mijnbouw en arbeidsmarkt, pp. I 86-192.

82. Leboutte, "Coal Mining, Foreign Workers and Mine Safety"; Christoph Rass and Florian Wöltering, "Migration und Sozialregion: Wanderungsbeziehungen zwischen europäischen und außereuropäischen Bergrevieren", in Angelika Westermann (ed.), Montanregion als Sozialregion. Zur gesellschaftlichen Dimension von "Region" in der Montanwirtschaft (Husum, 2012), pp. $59-89,70$. 
"guestworkers", as they were called (from the German word Gastarbeiter), were again recruited on the basis of bilateral treaties to regulate migration according to the needs of the economy. ${ }^{{ }_{3}}$

In all coal-producing countries in western Europe (excluding Britain) "guestworkers" were employed in coalmining on a relatively large scale. To provide for workers in Germany, for instance, a German-Turkish "Regelung der Vermittlung türkischer Arbeitnehmer nach der Bundesrepublik Deutschland" [Settlement to Procure Turkish Employees for the Federal Republic of German] was signed in I96I to regulate the selection and mediation of Turkish contract workers by German agencies in Istanbul and Ankara. By I963 Io,200 Turkish miners were already employed in German coalmining, the largest group among the 27,130 foreign workers in that industry. ${ }^{84}$ After a relapse during the recession of $1966-1967$, their number rose again, from about 5,200 in 1969 to 19,800 in 1973 , accounting for 74 per cent of all foreign workers in coalmining. ${ }^{85}$ The stark fluctuation of these numbers before, during, and after the recession of $1966-1967$ reflects the general position of foreign workers as a flexible reserve army, both in coalmining and other sectors. Although by 1973 several German mines were staffed almost exclusively by miners of Turkish descent, in most cases Turks were to be found only at the lower end of the job ladder. As with the Moroccan workers in other European coal-producing countries, they were often employed to ensure exhausted or unprofitable mines could be closed down smoothly. ${ }^{86}$

Moroccan migrants were the last group of miners recruited for the coal industry on the basis of bilateral treaties. Their main destinations were France, Belgium, and the Netherlands. In the interwar years, small numbers had already arrived in the mining districts of northern France, and from there into Belgium. ${ }^{87}$ In the late 1950 s and early i960s migration to northern France, Belgium, and the Netherlands started to grow, at first spontaneously, then in Morocco itself through recruitment by employers' organizations, but also through family networks. Once in the region, Moroccan migrants easily crossed the borders between France, Belgium, and the Netherlands, whose coalfields were situated relatively close to each other. Treaties with Morocco to regulate migration officially were signed in 1963 with France, in 1964 with Belgium, and in 1969 with the Netherlands.

83. Rass, Institutionalisierunsprozesse auf einem internationalen Arbeitsmarkt, passim.

84. Karin Hunn, "Nächstes Jahr kehren wir zurück ...". Die Geschichte der türkischen

'Gastarbeiter' in der Bundesrepublik (Göttingen, 2005), pp. 107-I09.

85. Ibid., p. 213.

86. Ibid., pp. 219-22 I.

87. Marie Cegarra, La mémoire confisquée: les mineurs marocains dans le Nord de la France (Villeneuve-d'Ascq, 1999), pp. 45-46; idem, "Récession et immigration: les mineurs marocains dans les mines de charbon du Nord/Pas-de-Calais", in Jean-François Eck, Peter Friedemann, and Karl Lauschke (eds), La reconversion des bassins charbonniers. Une comparison interrégionale entre la Rubr et le Nord-Pas-de-Calais (Villeneuve-d'Ascq, 2006), pp. I 57-I64. 
The treaties enabled the entry of a growing number of Moroccan immigrants into the mines of these countries, in two waves: the first until the recession of $1966-1967$, the second in the early 1970s. A total of 20,495 Moroccan immigrants arrived in France between 1960 and $1965 ;$ their number reached 78,000 in $1977 .{ }^{88}$ Migration to Belgium and the Netherlands was less substantial in absolute terms (several thousands), but Moroccans became by far the largest group of foreigners in the Belgian and Dutch mines in the 1970s. ${ }^{89}$ In the decaying coal industry in these countries, mining companies were unable to hold a local workforce. Miners and their sons took a bleak view of future opportunities in coalmining and started to look for employment outside the mines. Moroccan miners were brought in on short-term contracts to compensate for shortages of local workers and to help pit closures to proceed in an orderly manner..$^{90}$ In the 1970 s they were recruited for the Lorraine coalmines in France with this same goal in mind. $9^{\mathrm{I}}$

\section{MIGRANTS IN THE MINING COMMUNITY}

While debates on ethnic and racial discrimination and segregation, as against solidarity and integration, in miners' unions have a certain tradition in mining labour history, the focus of historical research since the I 990 s has shifted from the relationship of class, race, and ethnic identity in workers' struggles to other aspects. New approaches have allowed scholars to shed light on issues such as racial discrimination, ethnic segregation, social integration, and the intricate processes of identity formation among migrants in the context of mining communities. At the same time, the concept of the "mining community" itself, as a closed, homogeneous, and often isolated settlement, dominant for a while in (especially British) sociology and mining history, ${ }^{92}$ has come under scrutiny, precisely because of the diversity of its inhabitants. ${ }^{93}$ As early as 1992 the late Klaus Tenfelde wrote:

One such difference was that between residents and newcomers; another was the ethnic difference between, for example, the Irish [...] and the English and

\section{Cegarra, La mémoire confisquée, p. 53.}

89. Karim Azzouzi, "Les Marocains dans l'industrie charbonnière belge", Brood en Rozen. Tijdschrift voor de geschiedenis van sociale bewegingen, 9 (2004), pp. 35-53; Tanja Cranssen, "Marokkaanse mijnwerkers in Limburg, 1963-1975", Studies over de sociaaleconomische geschiedenis van Limburg/ Jaarboek van het Sociaal Historisch Centrum voor Limburg, 48 (2003), pp. I 2 I-I 48.

90. Ibid., pp. I45-I46; Cegarra, "Récession et immigration", p. I27.

91. Piero-D. Galloro, Tamara Pascutto, and Alexia Serré, Mineurs algériens et marocains. Une autre mémoire $d u$ charbon lorrain (Paris, $20 \mathrm{I}$ I), pp. 45-7I.

92. The classic text is Martin Bulmer, "Sociological Models of the Mining Community", Sociological Review, 23 (1975), pp. 6 I-92. See also Norman Dennis, Fernando Henriques, and Clifford Slaughter, Coal is our Life: An Analysis of a Yorkshire Mining Community (London, 1956).

93. Mining communities in Britain are sometimes supposed to be less ethnically diverse than those in Europe and America. For an alternative view on the British case, see David Gilbert, "Imagined Communities and Mining Communities", Labour History Review, 60:2 (1995), pp. 47-55. 
Americans, as well as between the Polish and the Germans. These ethnic differences weighed all the more heavily since $[\ldots]$ it was possible to link them to religious difference $[\ldots] .^{94}$

The shift towards the study of migration and ethnicity in mining communities is clearly visible in the landmark volume on comparative coalfield history edited by Stefan Berger et al., published thirteen years later (in 2005). Several chapters deal with "identities", "communities", and with the "interlocking spheres of workplace, neighbourhood, family, and working-class organizations", including the one by Leen Beyers on "ethnic, class and gender identities at street level” in the Belgian miners' colony (cité) of Zwartberg. ${ }^{95}$ In this article she arrives at a fairly positive assessment of the inter-ethnic interaction between Flemish, Polish, Czech, and Italian neighbours. Elsewhere, she compares the construction and deconstruction of ethnic boundaries between second-generation migrants of Polish and Italian origin and Belgian nationals in this cité. ${ }^{96}$ The time lag in the arrival of these different groups of immigrants also caused a time lag in the social integration of their children. However, both groups of migrants really succeeded in being accepted as "Belgians" only after the arrival of new groups of Islamic migrants, predominantly from Turkey. The (perceived) distinctiveness of these new outsiders led to the view by the local population (many of them former migrants or descendants of migrants) that migrants from former migration waves had successfully integrated.

Comparable issues have been raised in the German Ruhr in discussions on the similarities and differences between Polish migration in the more distant past and Turkish immigration in the recent past. ${ }^{97}$ While historical

94. Klaus Tenfelde, “The Miners' Community and the Community of Mining Historians", in idem (ed.), Towards a Social History of Mining in the Igth and 20th Centuries (Munich, 1992), pp. I20I-I2I 5, I 207. The volume itself, which brought together a selection of around seventy conference papers, contained only one on this issue of ethnicity: Mildred A. Beik, "The Competition for Ethnic Community Leadership in a Pennsylvania Bituminous Coal Town, I890s-1930s", in ibid., pp. 223-24I.

95. Leen Beyers, "Everyone Black? Ethnic, Class and Gender Identities at Street Level in a Belgian Mining Town, 1930-50", in Berger et al., Towards a Comparative History of Coalfield Societies, pp. I46-163.

96. Leen Beyers, "From Class to Culture: Immigration, Recession, and Daily Ethnic Boundaries in Belgium, I940s-1990s", International Review of Social History, 53 (2008), pp. 37-61.

97. Aloys Berg, "Polen und Türken im Ruhrkohlenbergbau. Ein Vergleich zweier Wanderungsvorgänge mit einer Fallstudie über 'Türken im Ruhrgebiet'” (Ph.D. dissertation, University of Bochum, I990); Diethelm Blecking, "Polish Community before the First World War and Present-Day Turkish Community Formation: Some Thoughts on a Diachronistic Comparison", in John Belchem and Klaus Tenfelde (eds), Irish and Polish Migration in Comparative Perspective (Essen, 2003), pp. I 83-200; Leo Lucassen, "Poles and Turks in the German Ruhr Area: Similarities and Differences", in Leo Lucassen, David Feldman, and Jochen Oltmer (eds), Paths of Integration: Migrants in Western Europe (I880-2004) (Amsterdam, 2006), pp. 27-45; Klaus Tenfelde, "Schmelztiegel Ruhrgebiet? Polnische und tūrkische Arbeiter im Bergbau: Integration und 
research, like that presented by Diethelm Blecking in this Special Issue, has established a clear relationship between the segregation of and discrimination against Polish miners before World War I and the emergence of a strong feeling of national identity among them, the supposedly easy integration of Polish migrants in the past has repeatedly been invoked in public discourse as a counter-story pointing to the lack of integration of their Turkish counterparts today. The supposedly opposite behaviour of Polish and Italian migrants on the one hand and Turkish migrants on the other serves in this discourse to disqualify the ability of Islamic migrants to adapt to "Western" culture. From a historians' perspective this is much more ambiguous, however. ${ }^{98}$ In her article in this Special Issue on what the French call la sociabilité sportive, especially football, in the coalfield of Nord-Pas-de-Calais, Marion Fontaine argues that the possibilities open to migrants to participate in the sporting community depended on the social conditions in mining. Unlike the Polish footballers in the mining villages in the interwar years, migrants from the Maghreb (Morocco and Algeria) arriving after World War II could not be incorporated into professional football because the mining communities were already in dissolution owing to the decline of the mining industry since the I960s. ${ }^{99}$

Marion Fontaine's case study points to the fact that opportunity structures and circumstances change considerably over time, which makes it difficult to compare (ceteris paribus, as it were) trajectories of migrants of different descent arriving in different periods of time. Other historians, however, have argued that the difference might not be that significant, because, depending on the time-frame under consideration, it often takes several generations for migrant minorities to overcome segregation and discrimination and to integrate socially and culturally. ${ }^{100}$

The comparability of "old" (nineteenth- and early twentieth-century) and "new" (late twentieth-century) migrants has been questioned, however, especially in the United States, where theories about a pattern of initial migrant segregation and subsequent integration over several generations have a long tradition, dating from the so-called Chicago School of migration research in the 1920 and 1930 s. ${ }^{101}$ In this debate, migration historians seem

Assimilation in der montanindustriellen Erwerbsgesellschaft", Mitteilungsblatt des Instituts für soziale Bewegungen, 36 (2006), pp. 7-28.

98. See, for instance, the uneasy integration of Italian migrants in the Walloon coalfields: Flavia Cumoli, "Perdus dans le paysage: la prolongation de la culture rurale italienne dans les bassins miniers de Wallonie", Revue belge d'histoire contemporaine, 37 (2007), pp. 419-443.

99. See also Marion Fontaine, "Les 'Polaks' et les 'Sang et Or': une lecture sportive de la relation aux étrangers dans une ville minière", in Judith Rainhorn and Didier Terrier (eds), Étranges voisins. Altérité et relations de proximité dans la ville depuis le XVIIIe siècle (Rennes, 2010), pp. I I I-162. Io०. Leo Lucassen, The Immigrant Threat: The Integration of Old and New Migrants in Western Europe since I850 (Urbana, IL, 2005).

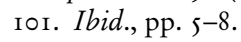


to be more confident about the applicability of this model, stressing parallels between the experiences of "old" and "new" migrants, than (several) social scientists, who argue that both present-day society and the (ethnic and religious) composition of the "new" immigrant groups in the United States (and also in Europe) differ dramatically from earlier ones. What seems important from a historical point of view, also in the context of ethnic relations among migrant miners, is that the social construction of ethnic and racial differences changed over time, for instance in the case of Irish, Italian, and "Slav" migrants in the United States, who were initially seen as racially inferior and who only gradually became "white".

This "process of whitening" has been explained partly by the mass migration of African Americans to the north, which enabled other (European) ethnic groups to be redefined as "whites" as opposed to "blacks". This is consistent with David Roediger's ideas about "whiteness" as a constructed racial identity in opposition to "blackness". ${ }^{102}$ Roediger's arguments have been criticized, however, as rather one-dimensional, because they ascribe a uniform racial identity to an abstract "white" working class, which itself remained sharply divided along lines of ethnicity and other divisions. ${ }^{103}$ Roediger himself cites the American writer Upton Sinclair, who in his novel King Coal gave a rather bleak picture of interethnic relations in a Colorado coal town around 1917: ${ }^{104}$

There were most rigid social lines in North Valley, it appeared. The Americans and English and Scotch looked down upon the Welsh and Irish; the Welsh and Irish looked down upon the Dagoes and Frenchies; the Dagoes and Frenchies looked down upon Polacks and Hunkies, these in turn upon Greeks, Bulgarians and "Montynegroes", and so on through a score of races of Eastern Europe: Lithuanians, Slovaks, and Croatians, Armenians, Roumanians, Rumelians, Ruthenians - ending up with Greasers, niggers, and last and lowest, Japs. ${ }^{\text {105 }}$

\section{CONCLUSION}

What becomes clear from this overview is that there was a huge difference between the migration and settlement of skilled miners, like those from Britain but also from other countries, and the recruitment of groups of unskilled workers from rural areas. What stands out as common in the cases mentioned is that these recruitments were often targeted at ethnic groups of

102. Roediger, Wages of Whiteness.

I03. Arnesen, "Up from Exclusion”, p. I64.

I04. David R. Roediger and Elizabeth D. Esch, The Production of Difference: Race and the Management of Labor in US History (Oxford, 201 2), p. 89.

I05. Upton Sinclair, King Coal: A Novel (New York, I917), p. 53. "Dagoes" is contemptuous slang for Italians, Spaniards, or Portuguese; "Hunkies" is an ethnic slur used to refer to a labourer from central Europe; "Greasers" is a derogatory term for Mexicans. 
a lower social status, not only because they were rural or unskilled, but also because they were considered inferior from a cultural or ethnic viewpoint.

Ethnic descent differentiated not only groups of migrants, however, but also an "established" workforce from "outsiders": ethnic minorities who were considered and treated as people of a lower status than the dominant ethnic group. In many cases the recruitment of new ethnic groups proceeded in parallel with technological innovations in the mining industry, which deskilled large parts of the work and required an enlargement of the workforce by unskilled or semiskilled workers. Examples include the massive recruitment of Koreans in Japan in the late I920s, when work gangs in longwall mining replaced family teams at post-and-pillar mining; the employment of Chinese labourers in longwall mines on the Canadian west coast, replacing craft labour by semiskilled labour; the entry of "Slav" and Italian migrant miners in the Pennsylvania coalmines, which went hand in hand with the introduction of coal-cutting machines and the deskilling of mine work; and the recruitment of inexperienced Italian migrants in the French and Belgium mines after World War II, whose deployment had been made possible by the introduction of new mining methods and technologies.

The ethnic divisions in the workforce were therefore blurred with divisions of skill and hierarchy. This explains the negative, or sometimes even racist, attitudes of early arrivers, mainly skilled white miners, and their descendants, towards newcomers, not only blacks, as in South Africa and the United States, but also newly arrived migrants of other complexities and looks, such as eastern Europeans or Italians. Status and ethnic prejudice enforced each other also in the social relations between migrant families in the mining communities. The longer-term consequences of these divisions are, however, much less clear. Studies on the segregation and integration of different ethnic groups in European and United States coalmining give mixed results, both in relation to trade unions and daily life. Comparisons of "old" (late nineteenthand early twentieth-century) and "new" (late twentieth-century) migration reveal great differences, which can perhaps be attributed to the shorter timeframe of the latter, but more likely to the persistent discrimination of the new migrant groups in Europe and the United States from the I970s.

The picture, however, is far from complete, as it does not include knowledge about the dynamics in and around coalfields in other world regions. Coalmining (and mining in general) has had, and still has, a particular tendency to reshape both the natural and social surroundings of its locations, reshuffling, through the quest for a workforce amenable to the operator's needs, the ethnic and social composition of the mining communities many times over. The processes of segregation and integration, of exclusion and inclusion, and of solidarity and fragmentation, will thus be found in other parts of the world too. The degree to which other places follow the European and North American pattern remains to be ascertained. 